\title{
Developing GIS-based water poverty and rainwater harvesting suitability maps for domestic use in the Dead Sea region (West Bank, Palestine)
}

\author{
Sameer M. Shadeed ${ }^{1}$, Tariq G. Judeh ${ }^{1}$, and Mohammad N. Almasri ${ }^{2}$ \\ ${ }^{1}$ Water and Environmental Studies Institute, An-Najah National University, Nablus, West Bank, Palestine \\ ${ }^{2}$ Civil Engineering Department, An-Najah National University, Nablus, West Bank, Palestine
}

Correspondence: Sameer M. Shadeed (sshadeed@najah.edu)

Received: 21 June 2018 - Discussion started: 28 June 2018

Revised: 25 February 2019 - Accepted: 26 February 2019 - Published: 18 March 2019

\begin{abstract}
In the arid region of the Dead Sea, water shortage and the inability to satisfy the increasing domestic water demand threatens sustainable development. In such situations, domestic rainwater harvesting is considered an efficient way to combat water poverty. This paper aims to develop domestic water poverty (DWP) and domestic rainwater harvesting suitability (DRWHS) maps for the West Bank, Palestine. The analytical hierarchy process (AHP) and the GIS-based weighted overlay summation process (WOSP) were utilized in the development of these maps. Results of the DWP map indicate that $57 \%$ of the West Bank is under high to very high poverty of domestic water. The DRWHS map shows that $60 \%$ of the West Bank is highly suitable for domestic rainwater harvesting. Spatial intersection (combined mapping) between DWP and DRWHS maps indicates that around $31 \%$ of the total West Bank areas could be classified as high potential locations (hotspot areas) for adopting rainwater harvesting techniques for domestic purposes. The developed maps are valuable to the stakeholders to better identify the best areas of rainwater harvesting in the West Bank.
\end{abstract}

\section{Introduction}

Water is a key factor for sustainable development. In the 21st century, the main challenge for millions of people worldwide is the lack of access to safe and clean water for domestic purposes (Worm and Hattum, 2006). In the West Bank (Palestine), water shortage is a problem that jeopardizes the sustainability of water availability for different uses (PWA,
2011). This situation deteriorated further due to the population growth and climate change that imposed a tremendous stress on the conventional water supplies (PWA, 2011). The existing political situation limits the Palestinians' accessibility to their water resources, and this further deepens the water problems (Judeh et al., 2017). In 2015, the estimated annual water supply-demand gap for domestic purposes for the entire West Bank was 32 million $\mathrm{m}^{3}$ (MCM) (PCBS, 2015).

DWP (domestic water poverty) is a term that describes the competency of water service providers to constantly provide customers with clean, sustainable and affordable domestic water (Feitelson and Chenoweth, 2002). It is measured by using an index called the domestic water poverty index (DWPI) (Sullivan et al., 2003). The DWPI can be attributed to several factors associated with water availability, socioeconomic conditions, environmental implications and the political situation (Coppin and Richards, 1990; Sullivan et al., 2003). DWP mapping is a simple and efficient approach to identify the spatial extent of water-poor/rich areas at different levels of jurisdiction areas (Thakur et al., 2017). This approach has been applied in the analysis of water stresses in many countries all over the world such as the US (James et al., 2007), Nepal (Thakur et al., 2017) and Palestine (West Bank) (Isaac et al., 2008).

A DWP map has several pros as it demonstrates the relationship between the physical availability of water, its quality and suitability for domestic use, and its accessibility. It is also a tool for monitoring programs in the water sector, and it helps in improving the situation of communities that suffer from water poverty (van der Vyver and Jordaan, 2011). 
Generally, water-poor areas should look for new, safe, sustainable and unconventional sources of water. For instance, rainwater harvesting $(\mathrm{RWH})$ is considered a viable alternative to secure water (Abdulrazzak, 2003). In arid and semiarid regions, adopting RWH will potentially enhance the economic, environmental and social development under uncertainty of water supply (UNEP, 2009). In Palestine, and given the uncertain groundwater supply, RWH is considered a sustainable option to bridge the increasing domestic water supply-demand gap (Shadeed, 2011).

$\mathrm{RWH}$ is the process of collecting and storing rainwater in order to be used afterwards for different uses among which is the domestic one (Gould and Nissen-Petersen, 1999). It is considered an ancient technology dating back to biblical times and was practiced in Palestine and Greece 4000 years ago (Critchley et al., 1991).

The use of RWH for domestic purposes entails that water quality is sufficiently good and within the permissible limits of drinking water quality standards. Mostly, the quality of harvested water can be controlled by proper practices (e.g., cleaning of the collecting surface such as roofs and removing the discharge of the first storm) and simple disinfections techniques when needed (African Development Bank, 2010; Meera and Ahammed, 2018).

In arid and semi-arid regions, domestic water productivity was enhanced by adopting RWH for many years (Boers et al., 1986; Bruins et al., 1986; Critchley et al., 1991; Abu-Awwad and Shatanawi, 1997; van Wesemael et al., 1998; Oweis et al., 1999; Li et al., 2000; Li and Gong, 2002; Rosegrant et al., 2002; Ngigi et al., 2005; Ngigi, 2006; Oweis and Hachum, 2006; Rockström and Barron, 2007; Mwenge Kahinda et al., 2007; Campisano et al., 2017; Singh and Turkiya, 2017; Tamaddun et al., 2018). In the West Bank, RWH is widely used at the household level in rural areas (Shadeed, 2011). About $50 \%$ of the entire West Bank area is classified as suitable to highly suitable for RWH for different uses (e.g., domestic and agricultural) (Shadeed, 2011). RWH is being practiced in the Faria catchment located in the northeastern part of the West Bank, and this helps in bridging the domestic water supply-demand gap (Shadeed and Lange, 2010).

This research aims at mapping the DWP and DRWHS (domestic rainwater harvesting suitability) maps for the entire West Bank. An integrated approach using GIS-based multicriteria decision analysis (MCDA) was adopted. The MCDA approach is widely used in DWP (van der Vyver and Jordaan, 2011; Thakur et al., 2017; Sullivan et al., 2003; Isaac et al., 2008) and RWH suitability studies (Shadeed, 2011; GalarzaMolina et al., 2015; Hussein and Shariff, 2015; Singh et al., 2016; Singhai et al., 2017; Jha et al., 2014).

The MCDA approach entails that the choice is built on a predetermined and limited number of decision variables (criteria) described by their attributes. Hence, the most influential criteria (layers) that affect both DWP and DRWHS mapping were identified, weighted and scored using AHP (analytical hierarchy process). The AHP approach was adopted

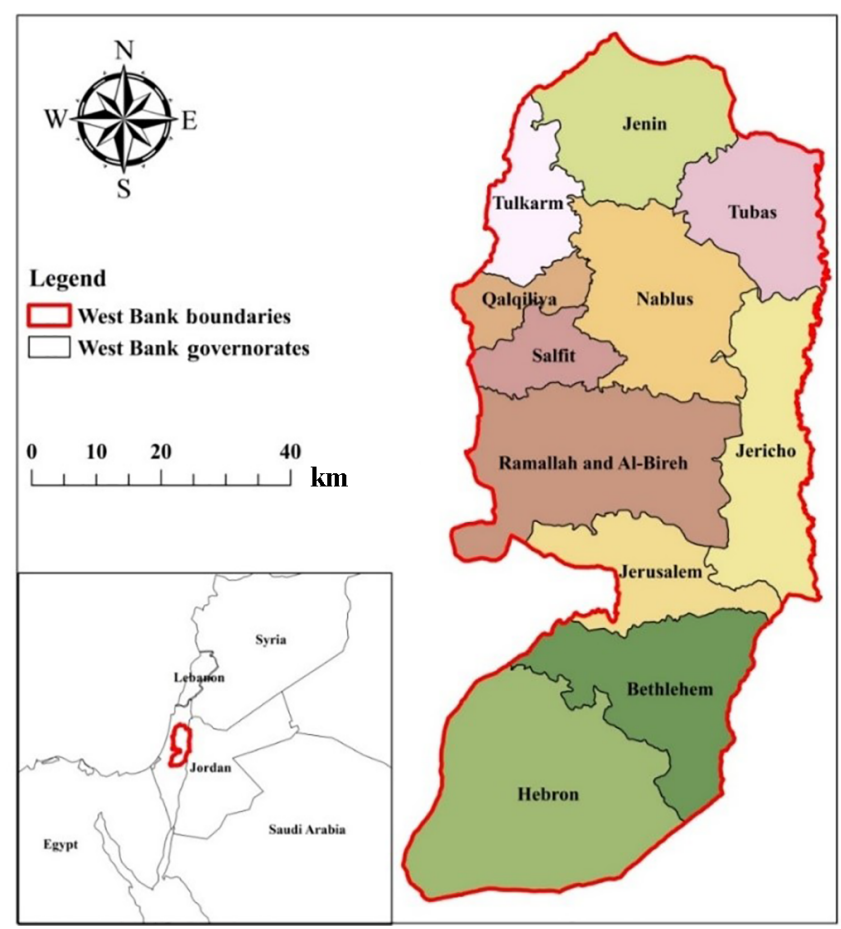

Figure 1. Regional setting of the West Bank.

by constructing a pairwise comparison matrix to assign relative importance (weight) for each criterion based on a preference scoring scale (Saaty, 1980). The GIS-based weighted overlay summation process (WOSP) was then used to develop both the DWP and DRWHS maps.

A key output in this research is the creation of spatial intersection between DWP and DRWHS maps for the entire West Bank. The developed map identifies the spatial distribution of water needs (water-poor areas) and spatial distribution of the potential of RWH techniques for domestic water use. This in turn can provide the key decision makers with a tool to identify potential locations where the implementation of RWH techniques could be most successful for domestic uses in Palestine.

\section{Materials and methods}

\subsection{Study area}

West Bank (Palestine) is located to the west of the Dead Sea. It has an area of about $5860 \mathrm{~km}^{2}$. Administratively, it is divided into 11 governorates with a total population of approximately 2.9 million (PCBS, 2017) (see Fig. 1).

The ground surface elevations range between $1022 \mathrm{~m}$ above mean sea level (a.m.s.l.) in the south (in Hebron) and $410 \mathrm{~m}$ below mean sea level (b.m.s.l.) in the proximity of the Dead Sea (in Jericho) (UNEP, 2003). The West Bank climate can be generally described as a Mediterranean one, which 


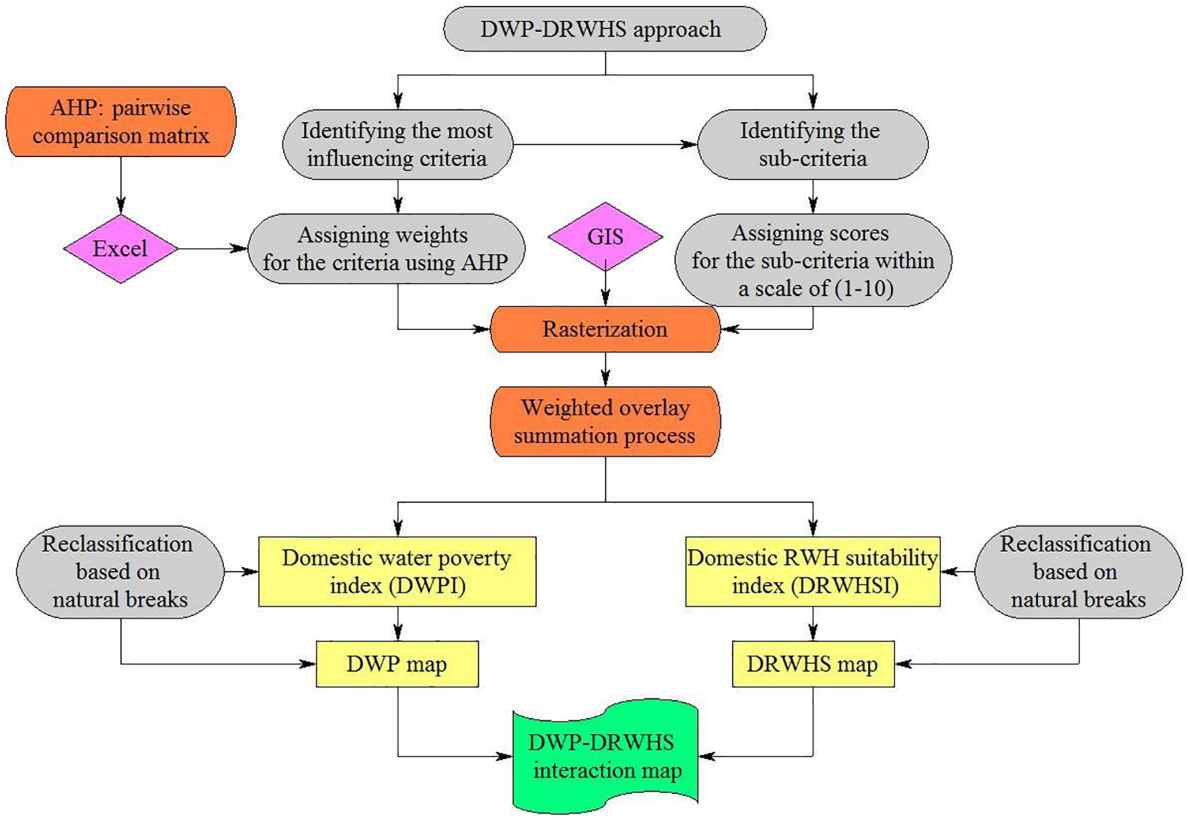

Figure 2. Methodological framework for developing DWP and DRWHS maps.

experiences extreme seasonal variations. The climate varies between hot dry in summer and wet cold in winter with short transitional seasons (Shadeed, 2008). Rainfall shows high spatial and temporal variation, with a long-term annual average of $450 \mathrm{~mm}$, which is equivalent to a rainfall volume of about 2500 MCM (PWA, 2013). Most of the annual rainfall (about $80 \%$ ) occurs in winter (Shadeed, 2012).

Water supply for different uses in the West Bank is very limited and does not suffice to satisfy the increasing water demand. The existing political situation adds another constraint on the availability and accessibility of water resources for Palestinians. Water supply is available either from local groundwater wells and springs or purchased from the Israeli water company Mekorot. In 2015, the domestic water supply-demand gap in the West Bank was 65 MCM (PCBS, 2015). Existing DRWH techniques (e.g., rooftops) contributed to about $4 \mathrm{MCM}$ for the domestic use in the West Bank (PWA, 2016).

Under average conditions, the West Bank has high runoff curve numbers with an average value of about 70 (Shadeed and Almasri, 2010). Needless to mention that a high curve number value implies a high runoff generation and this suits the implementation of the RWH techniques.

The land use map of the West Bank is classified into four main classes: rough grazing (62\%), agricultural practices $(32 \%)$, built-up areas $(5 \%)$ and Israeli settlements $(1 \%)$ (MoLG, 2017). The West Bank is characterized by different soil textures such as clay, clay loam, loamy, sandy loam and bare rock covering $47 \%, 31 \%, 9 \%, 8 \%$ and $5 \%$ of the study area respectively (MoLG, 2017). The elevations in the study area ranges from $375 \mathrm{~m}$ b.m.s.l. in the vicinity of the Dead
Table 1. Water poverty index (WPI) components and the associated influencing factors.

\begin{tabular}{ll}
\hline WPI key components & Influencing factors \\
\hline Access & Time to collect water (TCW) \\
& Losses in water networks (LWN) \\
& Population served by water networks (PSWN) \\
\hline Capacity & Productivity $(P)$ \\
& Citizens above poverty line (CAPL) \\
& Illiteracy $(I)$ \\
& Average unit price of water (AUPW) \\
\hline Environment & Population connected to sewer networks (PCSN) \\
& $\begin{array}{l}\text { Contaminated water samples by coliform }(\mathrm{CWSC}) \\
\mathrm{NO}_{3} \text { concentrations in groundwater }\left(\mathrm{NO}_{3}\right)\end{array}$ \\
\hline Resources & Per capita domestic water supply (PCDWS) \\
\hline Use & Per capita domestic water consumption (PCDWC) \\
\hline
\end{tabular}

Sea in Jericho to $1000 \mathrm{~m}$ a.m.s.l. in the mountains of Hebron (MoLG, 2017).

\subsection{Methodology}

The overall methodological framework used in this research for developing both DWP and DRWHS maps is illustrated in Fig. 2.

The water poverty index gives the water poverty considering five key components: access, capacity, environment, resource and use (Gould and Nissen-Petersen, 1999). The five key components were represented by 12 influencing criteria (see Table 1). For these criteria, data were collected from different sources which include the Palestinian Water Author- 
Table 2. AHP pairwise comparison matrix for the domestic water poverty index.

\begin{tabular}{lrrrrrrrrrrrrr}
\hline Criteria & TCW & LWN & PSWN & $P$ & CAPL & $I$ & AUPW & PCSN & CWSC & NO $_{3}$ & PCDWS & PCDWC & Weight \\
\hline TCW & 1.00 & 3.00 & 2.00 & 5.00 & 5.00 & 7.00 & 2.00 & 3.00 & 0.50 & 2.00 & 4.00 & 0.50 & 0.12 \\
LWN & 0.33 & 1.00 & 0.50 & 3.00 & 4.00 & 5.00 & 0.50 & 2.00 & 0.20 & 0.50 & 2.00 & 0.17 & 0.07 \\
PSWN & 0.50 & 2.00 & 1.00 & 4.00 & 5.00 & 5.00 & 2.00 & 3.00 & 0.50 & 2.00 & 4.00 & 0.33 & 0.10 \\
$P$ & 0.20 & 0.33 & 0.25 & 1.00 & 2.00 & 3.00 & 0.25 & 0.50 & 0.14 & 0.33 & 0.50 & 0.13 & 0.03 \\
CAPL & 0.20 & 0.25 & 0.20 & 0.50 & 1.00 & 2.00 & 0.25 & 0.33 & 0.14 & 0.25 & 0.50 & 0.13 & 0.02 \\
$I$ & 0.14 & 0.20 & 0.20 & 0.33 & 0.50 & 1.00 & 0.20 & 0.25 & 0.13 & 0.20 & 0.33 & 0.11 & 0.01 \\
AUPW & 0.50 & 2.00 & 0.50 & 4.00 & 4.00 & 5.00 & 1.00 & 3.00 & 0.33 & 2.00 & 3.00 & 0.25 & 0.09 \\
PCSN & 0.33 & 0.50 & 0.33 & 2.00 & 3.00 & 4.00 & 0.33 & 1.00 & 0.20 & 0.50 & 2.00 & 0.17 & 0.05 \\
CWSC & 2.00 & 5.00 & 2.00 & 7.00 & 7.00 & 8.00 & 3.00 & 5.00 & 1.00 & 4.00 & 6.00 & 0.50 & 0.18 \\
NO 3 & 0.50 & 2.00 & 0.50 & 3.00 & 4.00 & 5.00 & 0.50 & 2.00 & 0.25 & 1.00 & 3.00 & 0.20 & 0.08 \\
PCDWS & 0.25 & 0.50 & 0.25 & 2.00 & 2.00 & 3.00 & 0.33 & 0.50 & 0.17 & 0.33 & 1.00 & 0.14 & 0.04 \\
PCDWC & 2.00 & 6.00 & 3.00 & 8.00 & 8.00 & 9.00 & 4.00 & 6.00 & 2.00 & 5.00 & 7.00 & 1.00 & 0.21 \\
\hline
\end{tabular}

Table 3. The AHP pairwise comparison matrix for the domestic rainwater harvesting suitability index.

\begin{tabular}{lrrrrr}
\hline Criteria & RD & CN & SS & LU & Weight \\
\hline RD & 1.00 & 1.50 & 1.50 & 2.50 & 0.35 \\
CN & 0.67 & 1.00 & 1.50 & 2.50 & 0.31 \\
SS & 0.67 & 0.67 & 1.00 & 1.50 & 0.21 \\
LU & 0.40 & 0.40 & 0.67 & 1.00 & 0.13 \\
\hline
\end{tabular}

ity (PWA), Palestinian Central Bureau of Statistics (PCBS) and water service providers (e.g., municipalities). It is worth mentioning that the majority of the utilized data are available at a coarse resolution (e.g., governorate level). In the West Bank, rainwater is being harvested for domestic water supply using different techniques among which rooftops is the most important. Cisterns (pear shaped) and reservoirs are commonly used in the West Bank for storing the harvested rainwater (PWA, 2013). In general, the most influential criteria for DRWH suitability mapping in the West Bank were identified. These criteria are rainfall depth (RD), curve number (CN), surface slope (SS) and land use (LU). The spatial extent of the long-term average annual RD was obtained from the records of the existing rain gauges using the inverse distance weighting method (IDW). The $\mathrm{CN}$ map was developed for the entire West Bank (Shadeed and Almasri, 2010). A $25 \mathrm{~m} \times 25 \mathrm{~m}$ digital elevation model was processed to determine the SS layer. The LU map available at the Ministry of Local Government (MoLG) database was used.

Different weights were assigned for the different criteria used in each map by conducting the AHP pairwise comparison matrix. The matrices were filled using a scoring system (preference values) from 1 to 9 in order to reflect the preference and importance of the criteria (Saaty, 1980) (see Tables 2 and 3 ).

Once the pairwise comparison matrices were completed, the AHP provides researchers the opportunity to check and enhance the matrices' consistency. However, the matrices' consistency was measured by estimating the consistency ratio using the following formulas (Saaty, 1980):

$$
\begin{aligned}
& \mathrm{CR}=\frac{\mathrm{CI}}{\mathrm{RI}}, \\
& \mathrm{CI}=\frac{\lambda-n}{n-1},
\end{aligned}
$$

where $\mathrm{CR}$ is the consistency ratio, $\mathrm{CI}$ is the consistency in$\mathrm{dex}, \mathrm{RI}$ is a random consistency index, $\lambda$ is a normalized principal eigenvector and $n$ is the number of constraints (criteria).

The matrix is consistent if the CR value is smaller than or equal to 0.1 ; otherwise, it is considered inconsistent and needs to be revised (Saaty, 2000). According to the different preference values used in the pairwise comparison matrices shown in Tables 2 and 3, the CR values for DWP and DRWHS matrices are 0.04 and 0.01 respectively. So, both of them are consistent.

Each of the criteria used in DWP and DRWHS maps were divided into five sub-criteria, and each of them were subjectively assigned a score from 1 to 10 (see Tables 4 and 5). For instance, values which are close to 10 have the highest DWP and DRWHS. Thereafter, rasterization (cell size of $100 \mathrm{~m}$ by $100 \mathrm{~m}$ ) of the different criteria based on their subcriteria scores was processed by GIS (see Figs. 3 and 4).

GIS is used to estimate DWPI and DRWHSI (DRWHS index) through the application of WOSP for the different layers (criteria) used. WOSP method applies a weighted linear formula in decision-making analysis (Store and Jokimäki, 2003). This method allows the manipulation of various spatial input layers by aggregating the weighted cell values together. Each input layer is multiplied by its assigned weight and the results are summed as (DWPI or DRWHSI) $j=$ $\sum_{i=1}^{n} W_{i} \cdot S_{i j}$, where (DWPI or DRWHSI) ${ }_{j}$ is the final cell index, $W_{i}$ is a normalized weight $\left(\sum W_{i}=1\right), S_{i j}$ is the score of the $i$ th cell with respect to the $j$ th layer and $n$ is the number of cells in each $j$ th layer (Malczewski, 1999). 


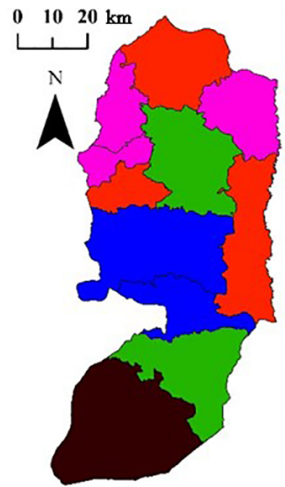

Legend

$\square$ West Bank governorates TCW

$\square 2 \square 4=6 \square 8=10$

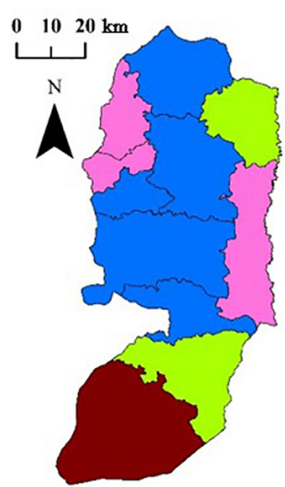

Legend

$\square$ West Bank governorates AUPW

$\square 1 \square 5 \square 7 \square 9$

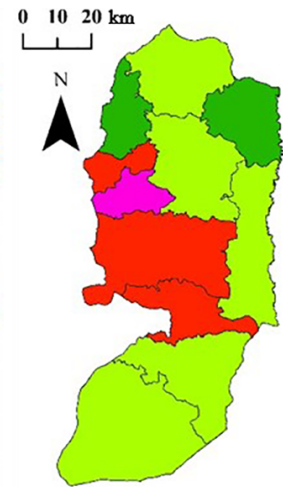

Legend

$\square$ West Bank governorates LWN

$-2 \square 4 \square 7 \square 8$

$\begin{array}{llll}0 & 10 & 20 & \mathrm{~km}\end{array}$

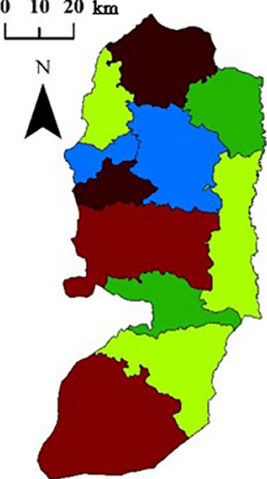

Legend

Legend
$\square$ WeSN

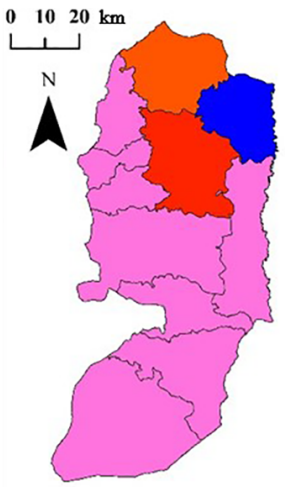

Legend

$\square$ West Bank governorates PSWN

$\square 1 \square 3 \square 4=6$

0 $1020 \mathrm{~km}$

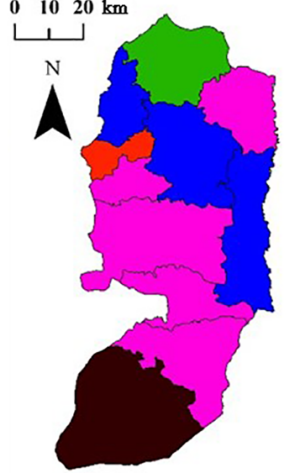

Legend

$\square$ West Bank governorates

CWSC

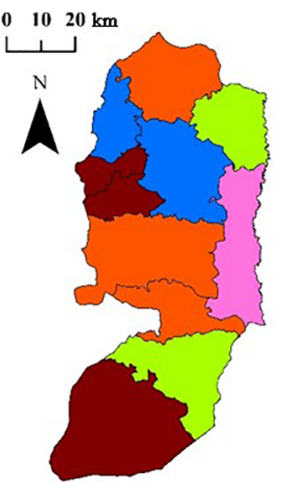

Legend

$\square$ West Bank governorates $\mathbf{P}$ CAPL $\square 1 \square 3 \square 5 \square 7 \square 9 \square 1 \square 3 \square 5 \square 7 \square 9$
$0 \quad 1020 \mathrm{~km}$
$0 \quad 1020 \mathrm{~km}$

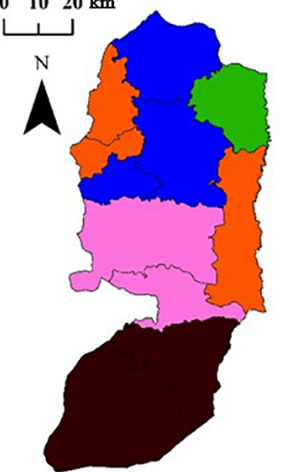

Legend

Legend Lend $\mathrm{NO}_{3}$
0 $10 \quad 20 \mathrm{~km}$
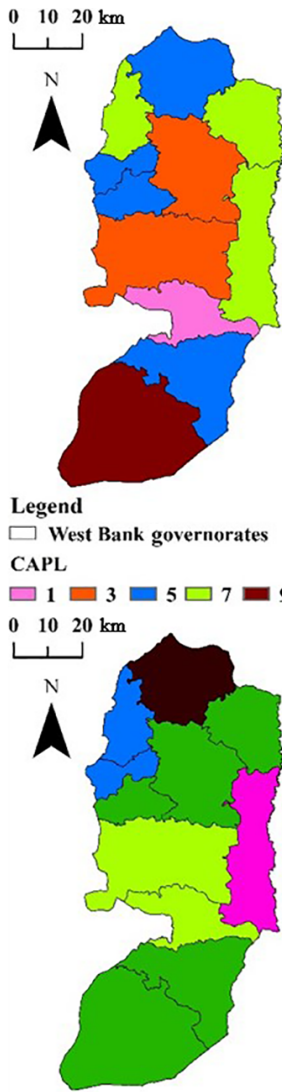

Legend

$\square$ West Bank governorates I

口 $2 \square 3 \square 5=6$
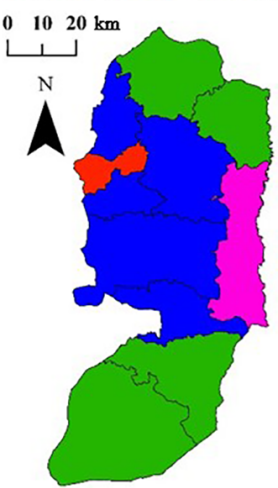

Legend

$\square$ West Bank governorates PCDWC

Figure 3. The score rasters of the 12 DWP criteria for the West Bank.

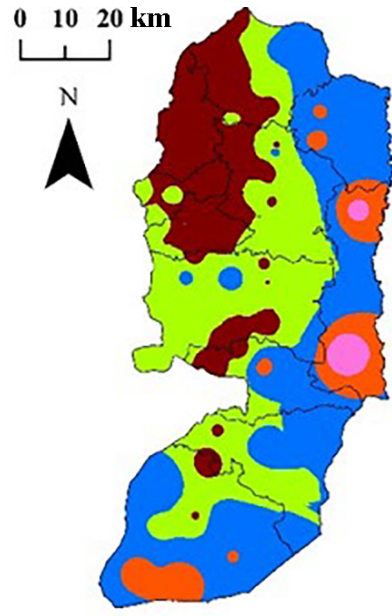

Legend

$\square$ West Bank governorates

$\mathrm{RD}$

$\square 1 \square 3 \square 5 \square 7 \square 9$

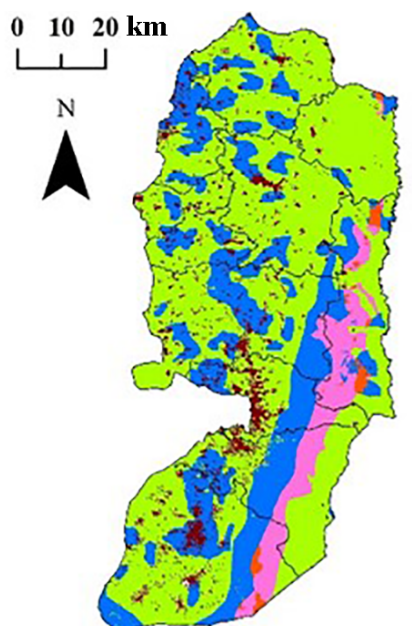

Legend

$\square$ West Bank governorates

CN

$\square 1 \square 3 \square 5 \square 7=9$

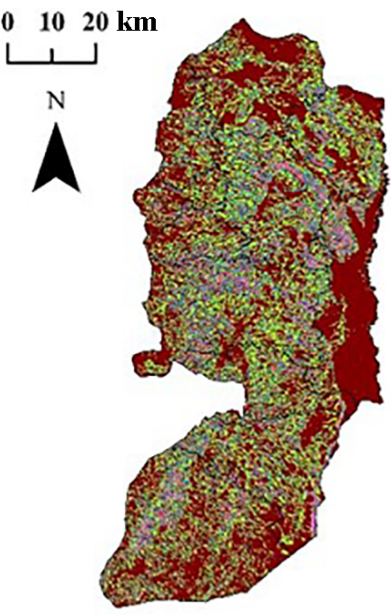

Legend

$\square$ West Bank governorates SS

$\square 1 \square 3 \square 5 \square 7 \square 9$

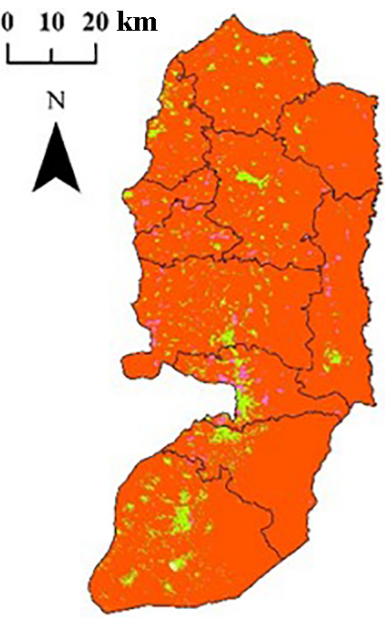

Legend

Z West Bank governorates LU

$\square 1 \square 3 \square 7$

Figure 4. The score rasters of the four DRWHS criteria for the West Bank. 
Table 4. DWP scoring assigned for the sub-criteria.

\begin{tabular}{|c|c|c|c|c|c|c|c|}
\hline Number & Criteria & Sub-criteria & Score & Number & Criteria & Sub-criteria & Score \\
\hline \multirow[t]{5}{*}{1} & TCW & $<6$ (days month $^{-1}$ ) & 10 & 7 & AUPW & $>5.2\left(\mathrm{NIS} \mathrm{m}^{-3}\right)$ & 9 \\
\hline & & $6-12$ & 8 & & & $4.6-5.2$ & 7 \\
\hline & & $13-19$ & 6 & & & $3.9-4.5$ & 5 \\
\hline & & $20-26$ & 4 & & & $3.2-3.8$ & 3 \\
\hline & & $>26$ & 2 & & & $<3.2$ & 1 \\
\hline \multirow[t]{5}{*}{2} & LWN & $\geq 36(\%)$ & 8 & 8 & PCSN & $\leq 20(\%)$ & 10 \\
\hline & & $31-35.9$ & 7 & & & $21-30$ & 9 \\
\hline & & $26-30.9$ & 5 & & & $31-40$ & 8 \\
\hline & & $21-25.9$ & 4 & & & $41-50$ & 7 \\
\hline & & $<21$ & 2 & & & $>50$ & 5 \\
\hline \multirow[t]{5}{*}{3} & PSWN & $76-80(\%)$ & 6 & 9 & CWSC & $26-30(\%)$ & 10 \\
\hline & & $81-85$ & 5 & & & $21-25$ & 8 \\
\hline & & $86-90$ & 4 & & & $16-20$ & 6 \\
\hline & & 91-95 & 3 & & & $11-15$ & 4 \\
\hline & & $96-100$ & 1 & & & $6-10$ & 2 \\
\hline \multirow[t]{5}{*}{4} & $P$ & < 1 (employee/1000 capita) & 9 & 10 & $\mathrm{NO}_{3}$ & $\geq 80\left(\mathrm{mg} \mathrm{L}^{-1}\right)$ & 10 \\
\hline & & $1.0-1.4$ & 7 & & & $60-79$ & 8 \\
\hline & & $1.5-1.9$ & 5 & & & $40-59$ & 6 \\
\hline & & $2.0-2.4$ & 3 & & & $20-39$ & 3 \\
\hline & & $\geq 2.5$ & 1 & & & $<20$ & 1 \\
\hline \multirow[t]{5}{*}{5} & CAPL & $65.1-72(\%)$ & 9 & 11 & PCDWS & $<80$ & 10 \\
\hline & & $72.1-79$ & 7 & & & $80-119$ & 8 \\
\hline & & $79.1-86$ & 5 & & & $120-159$ & 7 \\
\hline & & 86.1-93 & 3 & & & $160-199$ & 5 \\
\hline & & $93.1-100$ & 1 & & & $\geq 200$ & 2 \\
\hline \multirow[t]{5}{*}{6} & I & $4.5-5.0(\%)$ & 6 & 12 & PCDWC & $<40$ & 10 \\
\hline & & $3.9-4.4$ & 5 & & & $40-79$ & 8 \\
\hline & & $3.3-3.8$ & 4 & & & 80-119 & 6 \\
\hline & & $2.7-3.2$ & 3 & & & $120-159$ & 4 \\
\hline & & $2.1-2.6$ & 2 & & & $\geq 160$ & 2 \\
\hline
\end{tabular}

Table 5. The domestic rainwater harvesting suitability scoring assigned for the sub-criteria.

\begin{tabular}{|c|c|c|c|c|c|c|c|}
\hline Number & Criteria & Sub-criteria & Score & Number & Criteria & Sub-criteria & Score \\
\hline \multirow[t]{5}{*}{1} & \multirow[t]{5}{*}{$\mathrm{RD}$} & $153.0-262.1(\mathrm{~mm})$ & 1 & \multirow[t]{5}{*}{3} & \multirow[t]{5}{*}{ SS } & $\geq 24.0$ & 1 \\
\hline & & $262.2-371.3$ & 3 & & & $18-23.9$ & 3 \\
\hline & & $371.4-480.5$ & 5 & & & $12-17.9$ & 5 \\
\hline & & $480.6-589.7$ & 7 & & & $6-11.9$ & 7 \\
\hline & & $589.8-699.0$ & 9 & & & $\leq 5.9$ & 9 \\
\hline \multirow[t]{5}{*}{2} & \multirow[t]{5}{*}{$\mathrm{CN}$} & $\leq 50$ & 1 & \multirow[t]{5}{*}{4} & \multirow[t]{5}{*}{$\mathrm{LU}$} & Israeli settlements & 1 \\
\hline & & $51-60$ & 3 & & & Forest and rough grazing & 3 \\
\hline & & $61-70$ & 5 & & & Permanent crops and irrigated farming & 3 \\
\hline & & $71-80$ & 7 & & & Arable land & 3 \\
\hline & & $>80$ & 9 & & & Built-up areas & 7 \\
\hline
\end{tabular}

\section{Results and discussion}

\subsection{DWP map}

Figure 5 depicts the DWP map for the West Bank. Using the natural breaks approach, the map was classified into five water poverty categories: very low, low, moderate, high and very high.

Figure 5 shows that the governorates characterized by very high DWP are in the southern (Hebron) and northern parts (Jenin) of the West Bank which have $36 \%$ of the total West 


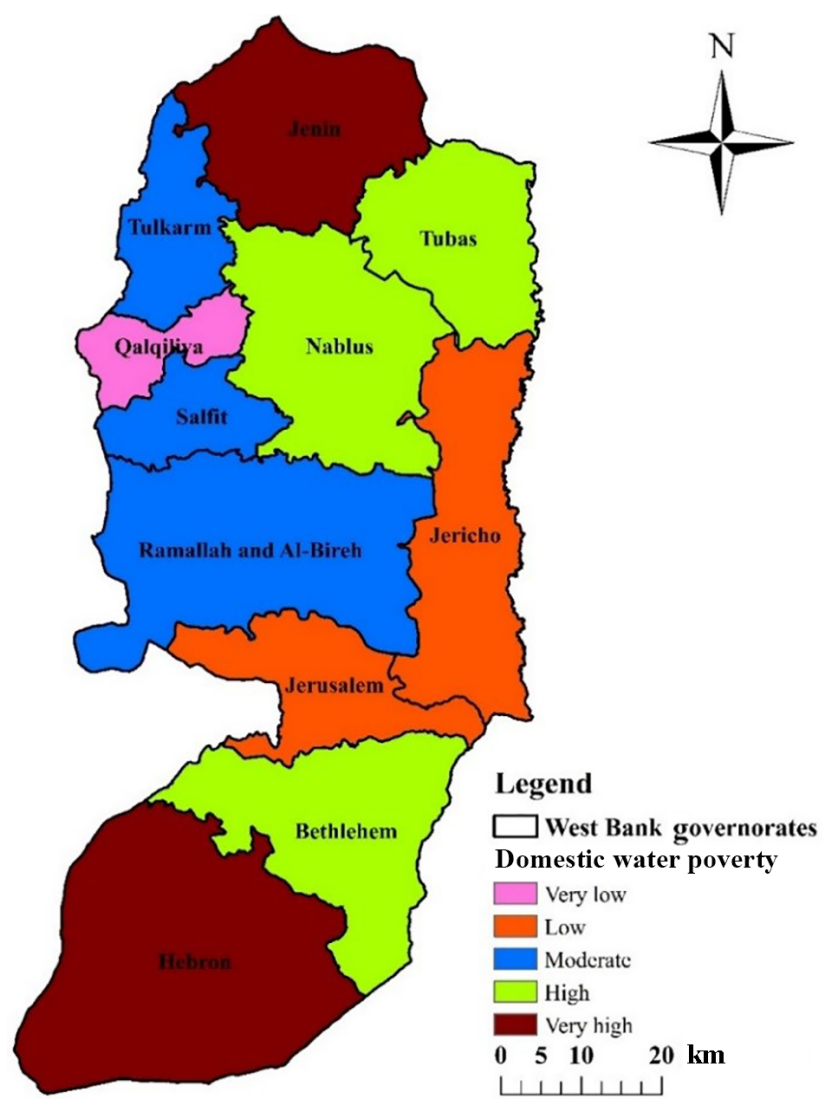

Figure 5. DWP map for the West Bank.

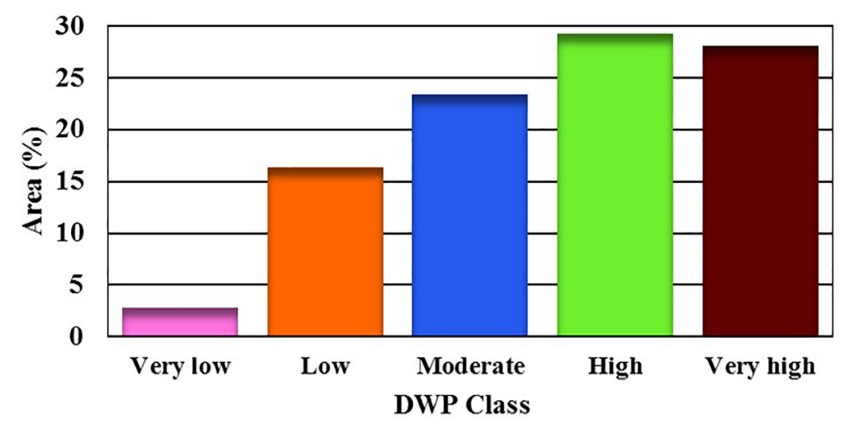

Figure 6. Area percentages of the different DWP classes in the West Bank.

Bank population (PCBS, 2017). The Bethlehem, Nablus and Tubas governorates suffer from high DWP conditions. In contrast, the results indicate that the Qalqiliya governorate has the lowest DWP, whereas low to medium DWP conditions are prevailing in the other governorates. However, the area percentages of the different DWP classes in the West Bank are presented in Fig. 6.

Generally, the results presented in the previous figure show the domestic-water-poor areas in the West Bank. High to very high DWP conditions cover $57 \%$ of the total West Bank area where $60 \%$ of Palestinians live. Moreover, the areas charac-

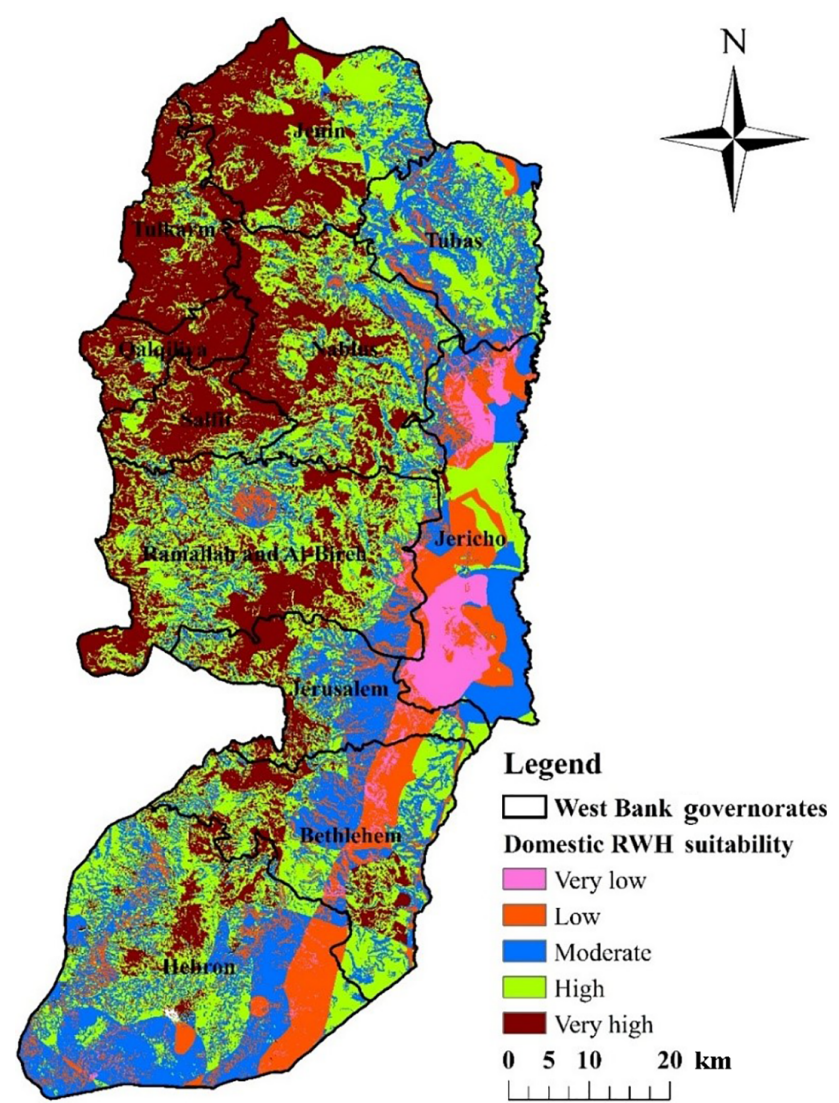

Figure 7. DRWHS map for the West Bank.

terized by moderate, low to very low DWP conditions occupy $43 \%$ of the total West Bank area, which includes $40 \%$ of the total West Bank population. Hence, there is a dire need to look into adaptive and sustainable domestic water alternatives among which RWH would be a successful one to alleviate domestic water shortage in the highly water-poor areas.

\subsection{DRWHS map}

Figure 7 shows the DRWHS map for the West Bank. As we did before, the map was classified into five suitability categories: very low, low, moderate, high and very high.

The developed DRWHS map indicates that the areas characterized as very high are distributed across the northwestern part of the West Bank, except for small portions that are located in the middle and southern mountains. In contrast, the eastern part of the West Bank is classified as very low to low areas. It is clear that the developed DRWHS map is highly influenced by both RD and CN criteria. This is because the trend for rainfall and runoff potential increases in the northwest and decreases in the southeast. The area percentages of the different DRWHS classes in the different West Bank governorates are illustrated in Fig. 8.

In general, about $60 \%$ of the total West Bank area is classified as high to very high for different DRWH techniques. 

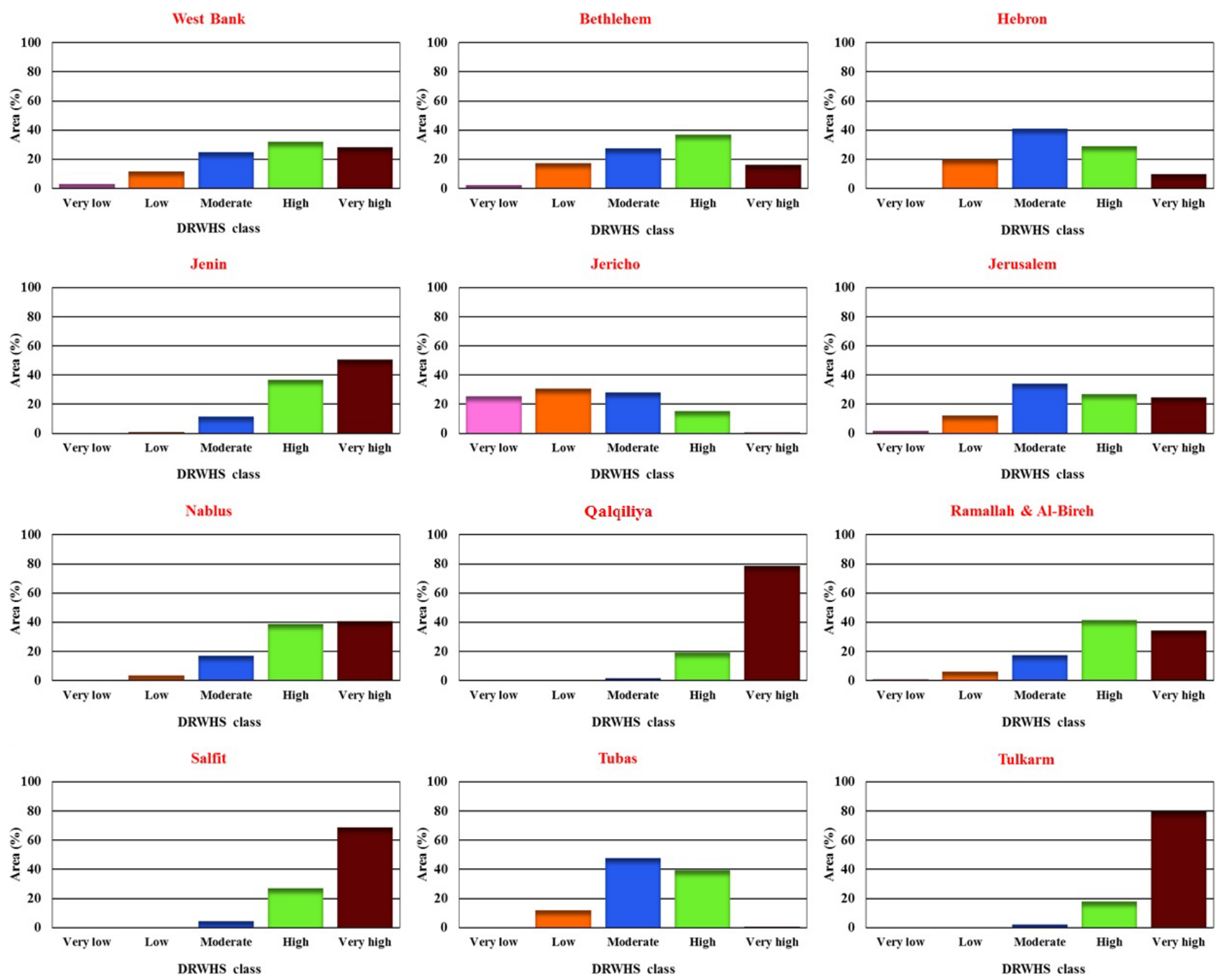

Figure 8. Area percentages of the different DRWHS classes in the different West Bank governorates.

Additionally, it is obvious that the high to very high DRWHS areas are dominant (70\%-95\%) in 6 out of 11 governorates. This indicates the high potential of adopting different DRWH techniques (e.g., rooftop) in trying to bridge the increasing domestic water supply-demand gap in the West Bank.

\subsection{DWPM-DRWHSM intersection}

The developed DWP and DRWHS maps urged the need to identify zones of high to very high DWP and DRWHS (hotspot areas). Accordingly, spatial intersections (combined mapping) between both maps were accomplished under the GIS environment for four intersection zones. These are very high poverty-very high suitability, very high povertyhigh suitability, high poverty-very high suitability, and high poverty-high suitability (see Fig. 9). Results indicate that hotspot areas are located mostly in the northern (Jenin, Tubas and Nablus) and southern (Bethlehem and Hebron) gover- norates of the West Bank. The area percentages of the four intersection zones are shown in Fig. 10. It is noticed that the four zones equal $31 \%$ of the total West Bank area. Such results can help decision makers to develop sustainable water management options among which proper DRWH techniques is the most important to satisfy domestic water needs predominantly in the identified hotspot areas.

The obtained results were verified using the available data of DRWH activities (digging of cisterns and building of reservoirs) in the middle and northern parts of the West Bank governorates for the period from 1994 to 2017 (PHG, 2018). Results are illustrated in Fig. 11. It is clear that DRWH activities in the last 22 years were concentrated (about $74 \%$ ) in the identified hotspot areas in the Nablus, Jenin and Tubas governorates. Thus, the adoption of DRWH techniques (e.g., rooftop) in these areas is of high importance to alleviate water shortage for domestic uses. The DWP and DRWHS combined mapping has several advantages. It is easy to use under 


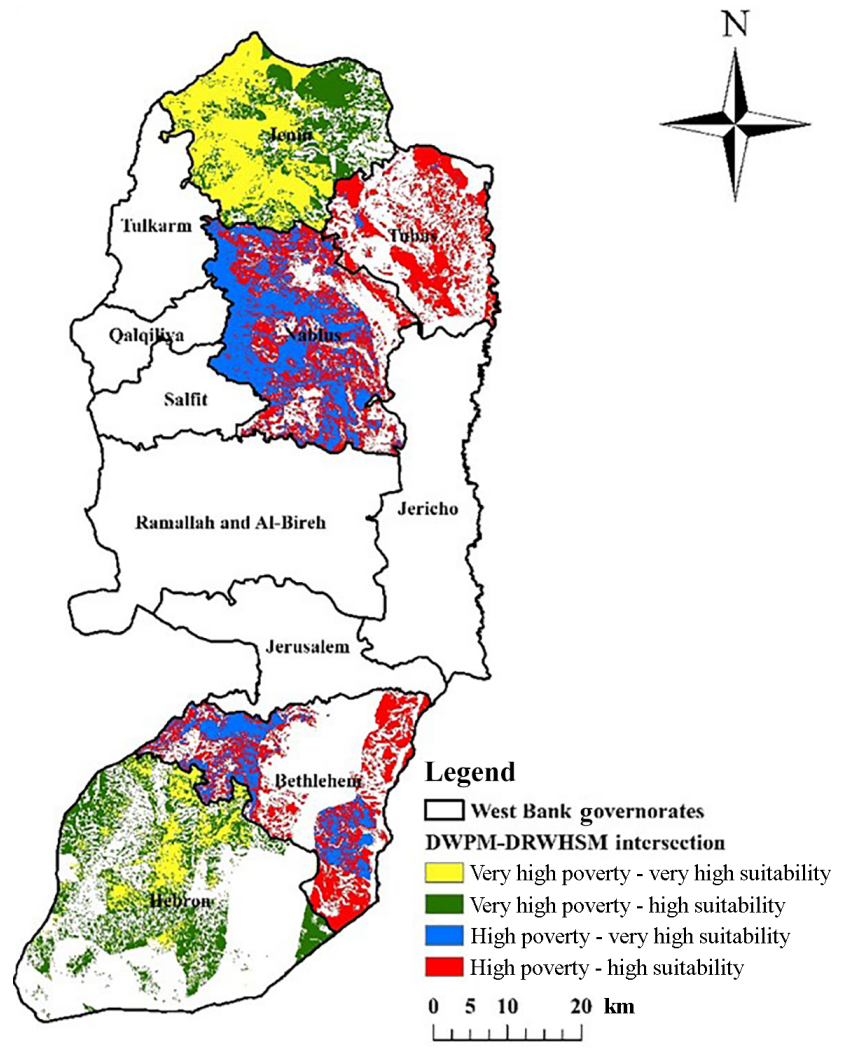

Figure 9. DWP-DRWHS map intersection for the entire West Bank.

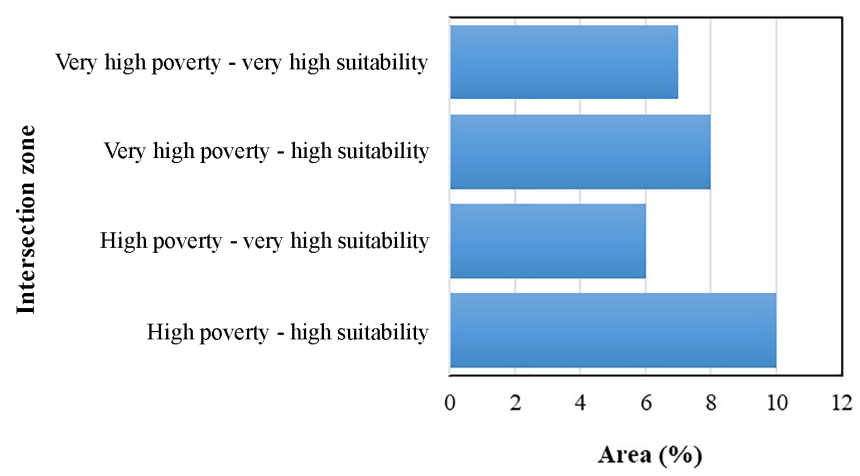

Figure 10. Area percentages of the four intersection zones.

the GIS environment, it can be applied at any region in the world once the driving factors (criteria) are made available and it helps decision makers to rely on DRWH techniques as a viable water management option for the benefit of end users in water-vulnerable areas. The method has some drawbacks. For instance, the accuracy of the developed map is highly influenced by the resolution and dynamic changes (e.g., urbanization) of the data. The socio-economic constraints were not considered in this study and need to be studied first in more detail for a realistic implementation of new RWH systems.

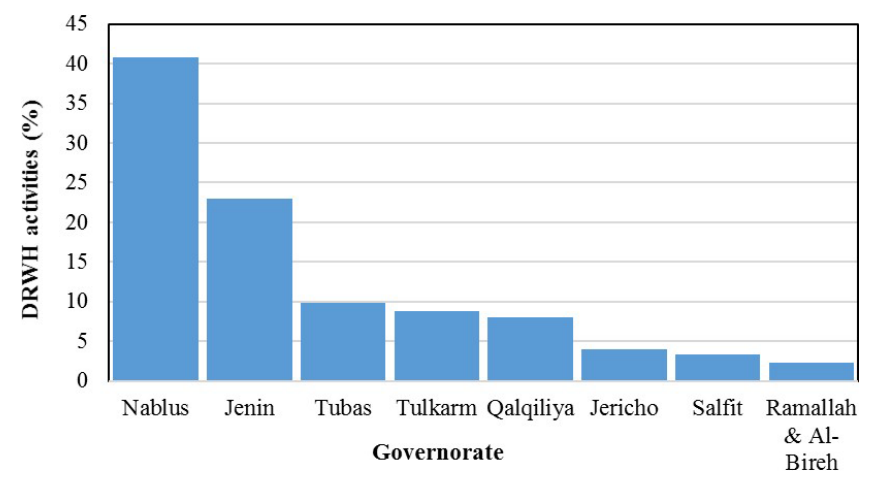

Figure 11. Percentages of DRWH activities in the northern governorates of the West Bank.

\section{Conclusions}

In this paper, maps of DWP and DRWHS were developed and utilized to identify the suitable locations for the implementation of water harvesting in order to reduce water poverty. The MCDA was employed to account for the influencing criteria according to their importance in the mapping of the DWP and DRWHS. The AHP pairwise comparison matrix approach was adopted to assign the criteria weights. Results show that $57 \%$ of the West Bank is under high to very high DWP. The DRWHS map indicates that high to very high suitable areas are concentrated in the north-western parts of the West Bank. The high to very high DWP and DRWHS areas account for more than $30 \%$ of the total West Bank area and are mostly located in the northern and southern parts. Since the MCDA entails subjectivity in assigning the weights and the scores, it is important to conduct a sensitivity analysis. This can be done by altering the weights and scores and thereafter examining the impacts on the DWP and DRWHS maps. Despite the fact that the available data are limited, this research managed to provide a novel insight towards the identification of high domestic-water-poor areas. This facilitates the implementation of different DRWH techniques that could be successful. This implies the applicability of this research in situations where data are limited. The work furnished herein assists the decision makers to derive proper water management strategies to bridge the gap between the supply and the demand in the West Bank. The results from this study can be applied to the entire Dead Sea region, which undergoes serious water shortage challenges. It is good to consider other spatial analysis levels for the development of the maps like the watershed outlines. Finally, further research is recommended to validate the combined map over different West Bank areas. 
Data availability. The GIS data used in this study can be found in the Supplement.

Supplement. The supplement related to this article is available online at: https://doi.org/10.5194/hess-23-1581-2019-supplement.

Author contributions. SMS was involved in the formulation of the general idea of the research, conceptual modeling, results interpretation, and manuscript preparation and writing. TGJ provided GIS processing and he was involved in the results presentation and manuscript preparation. MNA was involved in the manuscript editing and proofreading.

Competing interests. The authors declare that they have no conflict of interest.

Special issue statement. This article is part of the special issue "Environmental changes and hazards in the Dead Sea region (NHESS/ACP/HESS/SE inter-journal SI)". It is not associated with a conference.

Acknowledgements. This work was performed within the framework of the Palestinian Dutch Academic Cooperation Program on Water (PADUCO 2), funded by the Netherlands Representative Office (NRO) in Ramallah, Palestine. The financial support is gratefully acknowledged. We are also grateful to an anonymous reviewer and to Michel Riktsen, who improved our manuscript.

Edited by: Efrat Morin

Reviewed by: Michel Riksen and one anonymous referee

\section{References}

Abdulrazzak, M.: Water harvesting practices in selected countries of the Arabian Penisula, in: Proceeding of the Conference on Water Harvesting and the Future Development, Khartoum, Sudan, 1920 August 2003, 14 pp., 2003.

Abu-Awwad, A. M. and Shatanawi, M. R.: Water harvesting and infiltration in arid areas affected by surface crust: Examples from Jordan, J. Arid. Environ., 37, 443-452, https://doi.org/10.1006/jare.1997.0301, 1997.

African Development Bank: Assessment of best practices and experience in water harvesting: Rainwater harvesting handbook, ADB, Cote d'Ivoire, Open File Rep., 75 pp., 2010.

Boers, T. M., Zondervan, K., and Ben-Asher, J.: Micro-catchmentwater-harvesting $(\mathrm{MCWH})$ for arid zone development, Agr. Water Manage., 12, 21-39, https://doi.org/10.1016/03783774(86)90003-X, 1986.

Bruins, H. J., Evenari, M., and Nessler, U.: Rainwater-harvesting agriculture for food production in arid zones: The challenge of the African famine, Appl. Geogr., 6, 13-32, https://doi.org/10.1016/0143-6228(86)90026-3, 1986.
Campisano, A., D’Amico, G., and Modica, C.: Water saving and cost analysis of large-scale implementation of domestic rain water harvesting in Minor Mediterranean Islands, Water, 9, 916, https://doi.org/10.3390/w9120916, 2017.

Coppin, N. J. and Richards, I. G.: Use of Vegetation in Civil Engineering, 3rd edition, Construction Industry Research and Information Association, London, 1990.

Critchley, W., Siegert, K., Chapman, C., and Finkel, M.: Water harvesting: a manual for the design and construction of water harvesting schemes for plant production, Food and Agriculture Organization of the United Nations, Rome, Open File Rep., 154 pp., 1991.

Feitelson, E. and Chenoweth, J.: Water poverty: Towards a meaningful indicator, Water Policy, 4, 263-281, https://doi.org/10.1016/s1366-7017(02)00029-6, 2002.

Galarza-Molina, S., Torres, A., Moura, P., and Lara-Borrero, J.: CRIDE: a case study in multi-criteria analysis for decisionmaking support in rainwater harvesting, Int. J. Inf. Tech. Decis., 14, 43-67, https://doi.org/10.1142/S0219622014500862, 2015.

Gould, J. and Nissen-Petersen, E.: Rainwater Catchment Systems for Domestic Supply: Design, Construction and Implementation, Intermediate Technology Publications, London, 1999.

Hussein, F. and Shariff, R.: Selection of rainwater harvesting sites by using remote sensing and GIS techniques: A case study of Kirkuk, Iraq, Jurnal Teknologi, 76, , 75-81, https://doi.org/10.11113/jt.v76.5955, 2015.

Isaac, J., Gigliol, I., and Hilal, J.: Domestic water vulnerability mapping in the West Bank /Occupied Palestinian Territory, Applied Research Institute, Jerusalem, Open File Rep., 24 pp., 2008.

James, W., Lisa, H., and Rebecca, T.: Water and poverty in the United States, Geoforum, 38, 801-814, https://doi.org/10.1016/j.geoforum.2006.08.007, 2007.

Jha, M., Chowdary, V., Kulkarni, Y., and Mal, B.: Rainwater harvesting planning using geospatial techniques and multicriteria decision analysis, Resour. Conserv. Recy., 83, 96-111, https://doi.org/10.1016/j.resconrec.2013.12.003, 2014.

Judeh, T., Haddad, M., and Özerol, G.: Assessment of water governance in the West Bank, Palestine, Int. J. Global Environmental Issues, 16, 119-134, https://doi.org/10.1504/IJGENVI.2017.083426, 2017.

Li, F. R., Cook, S., Geballe, G. T., and Burch, W. R.: Rainwater harvesting agriculture: An integrated system for water management on rainfed land in China's semiarid areas, AMBIO, 29, 477-483, https://doi.org/10.1579/0044-7447-29.8.477, 2000.

Li, X. Y. and Gong, J. D.: Compacted microcatchments with local earth materials for rainwater harvesting in the semiarid region of China, J. Hydrol., 257, 134-144, https://doi.org/10.1016/S00221694(01)00550-9, 2002.

Malczewski, J.: GIS and Multicriteria Decision Analysis, John Wiley \& Sons Inc., New York, 1999.

Meera, V. and Ahammed, M.: Factors affecting the quality of roofharvested Rrainwater, in: Water Quality and Climate Change, Urban Ecology, edited by: Sarma, A., Singh, V., Bhattacharjya, R., and Kartha S., Springer, Berlin, Heidelberg, Germany, 195-202, https://doi.org/10.1007/978-3-319-74494-0_15, 2018.

MoLG.: Geomolg: Data set, Ministry of Local Government, available at: https://data-molg.opendata.arcgis.com/datasets (last access: 26 April 2018), 2017. 
Mwenge Kahinda, J., Taigbenu, A. E., and Boroto, R. J.: Domestic rainwater harvesting to improve water supply in rural South Africa, J. Phys. Chem. Earth., 32, 1050-1057, https://doi.org/10.1016/j.pce.2007.07.007, 2007.

Ngigi, S. N.: Hydrological impacts of land use changes on water resources management and socio-economic development of upper Ewaso Ng'iro river basin in Kenya, PhD thesis, UNESCOIHE/Technical University of Delft, Netherlands, 148 pp., 2006.

Ngigi, S. N., Savenije, H. H. G., Rockström, J., and Gachene, C. K.: Hydro-economic evaluation of rainwater harvesting and management technologies: Farmers' investment options and risks in semi-arid Laikipia district of Kenya, J. Phys. Chem. Earth., 30, 772-782, https://doi.org/10.1016/j.pce.2005.08.020, 2005.

Oweis, T. and Hachum, A.: Water harvesting and supplemental irrigation for improved water productivity of dry farming systems in West Asia and North Africa, Agr. Water Manage., 80, 57-73, https://doi.org/10.1016/j.agwat.2005.07.004, 2006.

Oweis, T., Hachum, A., and Kijne, J.: Water harvesting and supplemental irrigation for improved water use efficiency in dry areas, International Water Management Institute, Colombo, Open File Rep., 41 pp., 1999.

PCBS: Water Supply-Demand Statistics, Palestinian Central Bureau of Statistics, available at: https://tinyurl.com/y9vww487 (last access: 13 January 2018), 2015.

PCBS: Preliminary census results 2017, Palestinian Central Bureau of Statistics, Ramallah, Open File Rep., 82 pp., 2017.

PHG: Domestic rainwater harvesting techniques in the meddle and northern parts of the West Bank, Palestinian Hydrology Group, Ramallah, Open File Rep., 4 pp., 2018.

PWA: Annual status report on water resources, water supply, and wastewater in the Occupied State of Palestine, Palestinian Water Authority, Ramallah, Open File Rep., 97 pp., 2011.

PWA: Palestinian water sector: Status report of water resources in the occupied state of Palestine, Palestinian Water Authority, Ramallah, Open File Rep., 22 pp., 2013.

PWA: Water authority strategic plan 2016-2018, Palestinian Water Authority, Ramallah, Open File Rep., 25 pp., 2016.

Rockström, J. and Barron, J.: Water productivity in rainfed systems: Overview of challenges and analysis of opportunities in water scarcity prone savannahs, Irrigation Sci., 25, 299-311, https://doi.org/10.1007/s00271-007-0062-3, 2007.

Rosegrant, M. W., Cai, X., and Cline, S. A.: World water and food to 2025: Dealing with scarcity, International Food Policy Research Institute, Washington DC, Open File Rep., 338 pp., 2002.

Saaty, T. L.: The Analytic Hierarchy Process: Planning, Priority Setting, Resource Allocation, McGraw-Hill International Book Co., New York, 1980.

Saaty, T. L.: Fundamentals of decision making with the analytic hierarchy process, in: The Analytic Hierarchy Process in Natural Resource and Environmental Decision Making, edited by: Schmoldt, D. L., Kangas, J., Mendoza, G. A., and Pesonen, M., Springer, Dordrecht, 15-35, https://doi.org/10.1007/978-94-0159799-9_2, 2000.

Shadeed, S.: Up to Date Hydrological Modeling in Arid and Semiarid Catchment, the Case of Faria Catchment, West Bank, Palestine, PhD thesis, Faculty of Forest and Environmental Sciences, Albert-Ludwigs-Universität, Freiburg im Breisgau, Germany, 216 pp., 2008.
Shadeed, S.: Developing a GIS-based suitability map for rainwater harvesting in the West Bank, Palestine, The International Conference on Environmental Education for Sustainable Development: Plugging the Hole, Birzeit University, Palestine, 16-17 November 2011, 13 pp., 2011.

Shadeed, S.: Spatio-temporal drought analysis in arid and semiarid regions: A case study from Palestine, Arab. J. Sci. Eng., 38 , 2303-2313, https://doi.org/10.1007/s13369-012-0504-y, 2012.

Shadeed, S. and Almasri, M.: Application of GIS-based SCS-CN method in West Bank catchments, Palestine, Water Sci. Eng., 3, 1-13, https://doi.org/10.3882/j.issn.1674-2370.2010.01.001, 2010.

Shadeed, S. and Lange, J.: Rainwater harvesting to alleviate water scarcity under dry conditions: A case study in Faria catchment, Palestine, Water Sci. Eng., 3, 132-143, https://doi.org/10.3882/j.issn.1674-2370.2010.02.002, 2010.

Singh, L., Jha, M., and Chowdary, V.: Multi-criteria analysis and GIS modelling for identifying prospective water harvesting and artificial recharge sites for sustainable water supply, J. Clean. Prod., 142, 1436-1456, https://doi.org/10.1016/j.jclepro.2016.11.163, 2016.

Singh, O. and Turkiya, S.: Assessing potential for rooftop rainwater harvesting: An option for sustainable rural domestic water supply in arid region of Haryana, J. Rural Develop., 36, 49-60, 2017.

Singhai, A., Das, S., Kadam, A., Shukla, J., Bundela, D., and Kalashetty, M.: GIS-based multi-criteria approach for identification of rainwater harvesting zones in upper Betwa sub-basin of Madhya Pradesh, India, Environ. Dev. Sustain., 17, 1-21, https://doi.org/10.1007/s10668-017-0060-4, 2017.

Store, R. and Jokimäki, J.: A GIS-based multi-scale approach to habitat suitability modeling, Ecol. Model., 169, 1-15, https://doi.org/10.1016/S0304-3800(03)00203-5, 2003.

Sullivan, C., Meigh, J., Giacomello, A., Fediw, T., Lawrence, P., Samad, M., Mlote, S., Hutton, C., Allan, J., Schulze, R., Dlamini, D., Cosgrove, W., Priscoli, J., Gleick, J., Smout, I., Cobbing, J., Calow, R., Hunt, C., Hussain, A., Acreman, M., King, J., Malomo, S., Tate, E., O'Regan, D., Milner, S., and Steyl, I.: The water poverty index: Development and application at the community scale, United Nations Sustainable Development Journal, 27, 189-199, https://doi.org/10.1111/1477-8947.00054, 2003.

Tamaddun, K., Kalra, A., and Ahmad, S.: Potential of rooftop rainwater harvesting to meet outdoor water demand in arid regions, J. Arid Land, 10, 68-83, https://doi.org/10.1007/s40333-017-01107, 2018.

Thakur, J., Mahesh, N., and Mohanan, A.: Water poverty in upper Bagmati River Basin in Nepal, Water Sci., 31, 93-108, https://doi.org/10.1016/j.wsj.2016.12.001, 2017.

UNEP: Desk study on the environment in the Occupied Palestinian Territories, United Nations Environment Programme, Nairobi, Open File Rep., 194 pp., 2003.

UNEP: Rainwater harvesting: A lifeline for human well-being, United Nations Environment Programme, Stockholm, Open File Rep., 80 pp., 2009.

van der Vyver, C. and Jordaan, D.: Water poverty mapping and its role in assisting water management, Communications of the IBIMA, 2011, 941217, https://doi.org/10.5171/2011.941217, 2011.

van Wesemael, B., Poesen, J., Benet, A. S., Barrionuevo, L. C., and Puigdefábregas, J.: Collection and storage of runoff from 
hillslopes in a semi-arid environment: Geomorphic and hydrologic aspects of the aljibe system in Almeria Province, Spain, J. Arid Environ., 40, 1-14, https://doi.org/10.1006/jare.1998.0429, 1998.
Worm, J. and Hattum, V.: Rainwater harvesting for domestic use, Agromisa Foundation and CTA., Wageningen, Open File Rep., 85 pp., 2006. 